\title{
Knowledge and Practice as it Relates to the Recognition of Signs and Symptoms of Mental Health IIInesses in Children Among Nurses in Nassau Bahamas
}

\author{
Rebecca Johnson, BSN, MSN, Pediatric Nurse Practitioner
}

Princess Margaret Hospital, Nassau Bahamas

\section{INTRODUCTION}

Nurses who work in pediatric units are in an opportune position to observe, report and refer signs of possible mental health problems in children so that these children can receive the appropriate interventions at an early stage.

\section{AIM}

To enhance the knowledge and practice among nurses in an inpatient pediatric unit, in recognizing the possible signs of mental health problems in children.

\section{METHODOLOGY}

An action study method was used to explore the knowledge and practice of nurses, utilizing random sampling among nurses from the Pediatric Unit.

A pre and post test self-administered questionnaire was used for data collection.

The intervention consisted of providing information on contributing factors as well as the recognition of the possible signs and symptoms of mental illnesses in children in an effort to improve knowledge and enhance practice.

\begin{tabular}{|l|l|l|}
\hline \multicolumn{3}{|c|}{ ANALYSIS OF PRE/POST TESTS } \\
\hline $\begin{array}{l}\text { Possible signs and symptoms of mental } \\
\text { health problems in children }\end{array}$ & $\begin{array}{l}\text { \# change } \\
\text { from } \\
\text { False to }\end{array}$ & $\begin{array}{l}\text { from } \\
\text { False to }\end{array}$ \\
\hline 1. Changes is sleeping habits & True & True \\
\hline 2. Changes in eating habits & 9 & $24.3 \%$ \\
\hline 3. Poor school performance & 13 & $36.1 \%$ \\
\hline 4. Changes in personality & 11 & $28.2 \%$ \\
\hline 5. Use of tobacco or alcohol & 12 & $26.7 \%$ \\
\hline 6. Stealing & 10 & $37 \%$ \\
\hline 7. Fighting & 7 & $25.9 \%$ \\
\hline 8. Does not want to go to school & 7 & $22.6 \%$ \\
\hline 9. Does not like playing with other children & 11 & $29.4 \%$ \\
\hline 10. Irritability & 8 & $22.9 \%$ \\
\hline
\end{tabular}

\section{RESULTS}

93.3\% of the participants reported that they were now better able to recognize the signs and symptoms that may be indicative of possible mental health problems in children.

\section{SIGNIFICANCE}

Undetected and untreated mental health problems in children can have lifelong devastating effects. This research contributes to the body of knowledge in this area of research, nursing education and clinical practice.

\section{CONCLUSION}

Research in mental health in children can inform and enhance practice by equipping nurses with the necessary knowledge and assessment skills that will subsequently assist children in achieving optimal mental and emotional health

\section{REFERENCE}

Honeyman, C. (2007). Recognising mental health problems in children and young people. Paediatric Nursing. 19(8), 38-44.

Pryjmachuk, S., Graham, T., Haddad, M., Tylee, A.(2011). School nurses' perspectives on managing mental health problems in children and young people. Journal of Clinical Nursing, 21, 850-859.

Ravens-Sieberer, U. (2008).The contribution of the BELLA study in filling the gap of knowledge on mental health and well-being in children and adolescents in Germany. European Child Adolescent Psychiatry, 17, 5-9.

Reid-Searl, K., Dwyer, T., Happell, B., Moxham, L., Kahl, J., Morris, J., Wheatland, N.(2009). Caring for children with complex emotional and psychological disorders: experiences of nurses in a rural paediatric unit Journal of Clinical Nursing, 18, 3441-3449

Rydon, S. E.(2005).The attitudes, knowledge and skills needed in mental health nurses: The perspective of users of mental health services International Journal of Mental Health Nursing; 14, 78-87. 